\title{
In vitro digestibility response of cocksfoot (Dactylis glomerata L.) to growth and defoliation: a simple model
}

\author{
M. DURU,* E. FEUILLERAC AND H. DUCROCQ \\ INRA Agronomie, Chemin de Borde Rouge, BP27, 31326 Castanet Tolosan, France
}

(Revised MS received 6 August 1999)

\section{SUMMARY}

Herbage digestibility, which to a large extent governs the animal's intake, is not easily predicted for grazing animals, and can vary due to different grazing managements. The objective of this study was to build a model for a range of defoliation managements, which takes account of vegetative grass tiller structure, rather than dates of cutting or grazing, as done usually. An experiment was conducted in 1997, near Toulouse, to examine the digestibility of cocksfoot whole lamina and lamina segments $(15 \mathrm{~cm})$ for three defoliation regimes. These regimes mimicked severe and lenient intermittent defoliations plus a frequent defoliation treatment over a six-week period. Data were collected for (i) lamina mass and digestibility for the youngest expanded lamina, (ii) lamina appearance rate, lamina and sheath lengths.

Laminae digestibility, measured over time, varied greatly with the defoliation regime both for the youngest full expanded lamina and all laminae on a tiller. Digestibility of the youngest fully expanded lamina decreased from one leaf insertion level to the next, but this decrease was lowest when the defoliation regime was frequent. There was also a consistent decrease in the digestibility of a lamina from its tip to its base. Sheath and lamina lengths varied with treatment in a different way to lamina digestibility. During frequent defoliation, sheath and lamina lengths both increased slightly while they showed substantial increases in the two other treatments. Lamina length increased from one insertion level to the next, and resulted in the addition of less digestible lamina segments rather than reducing overall lamina digestibility. Sheath length, through its influence on leaf appearance rate and lamina length, could be used to predict the digestibility of laminae over time according to leaf insertion level and the difference in the digestibility observed from the tip to the base of a particular lamina. Sheath length could therefore provide a basis for predicting the time course of grass digestibility for different combinations of defoliation frequency and height.

\section{INTRODUCTION}

The effect of defoliation on herbage digestibility is usually only considered to be a function of grazing or cutting date (Demarquilly 1989; Fick et al. 1994). Such a model is adequate when herbage is cut for silage or hay, but not for grazing, particularly for vegetative regrowths of grazed grasses, mainly because defoliation may vary from severe to light (Wilkins 1995). For example, herbage digestibility may differ according to the amount of residual herbage or the interval between two defoliations (Kristensen 1988; Binnie \& Chestnutt 1994). Furthermore, the effects of grazing management are variable according to grow-

* To whom all correspondence should be addressed. Email:mduru@toulouse.inra.fr). ing season (Ducrocq \& Duru 1996). However, the reason for this is not known.

After defoliation, decreasing leaf digestibility depends on differences in digestibility due to both leaf insertion level and leaf ageing (Wilson 1976a). In numerous studies, it has been shown that during normal ontogenic drift (successive leaf insertion levels during growth), the lamina length increases according to the leaf insertion level, together with an increase in apparent leaf growth duration (outside the sheath) and a decrease in leaf appearance rate (Silsbury 1970; Wilson 1976a). These leaf characteristics are greatly dependent on sheath length. Length of a mature lamina at insertion level $i$ and sheath length corresponding to the leaf at insertion level $i-1$ were strongly correlated; the same being true for the sheath and the lamina at the same insertion level (Grant et al. 
1981; van Loo 1993). Thus, there is a close relationship between processes which take place inside the sheath, before the lamina emerges, and the characteristics of the mature lamina. The appearance of new leaves is influenced to a large extent by the length of the sheath tube through which the leaves emerge. In the spring and summer, the sheath length of leaves typically increases with increasing herbage mass and new leaves appear at successively increasing heights above ground (Wilson \& Laidlaw 1985; Davies, 1988; Skinner \& Nelson 1995). Furthermore, there is a difference in tissue composition from the tip to the base of the lamina, with the base containing a more structural component (Maurice et al. 1997).

Based on data in the literature which explains the influence that grazing management has on the digestibility of grass leaf, we suggest that sheath length governs lamina digestibility in two ways: (i) during normal ontogenic development, tillers produce increasingly longer laminae, made up by the addition of segments of decreasing digestibility, (ii) repeated defoliations maintain tillers with short sheaths producing laminae of the same length and digestibility. If these hypotheses are proven, the frequency and the intensity of defoliation should provide a way of manipulating the sward in order to reach a given herbage digestibility through the control of sheath length. Knowledge of such sward characteristics requires observations of laminae on both tillers and leaves. We have only considered the green leaf fraction, because it is known to be a key characteristic which determines herbage intake (Penning et al. 1996).

\section{MATERIALS AND METHODS}

\section{Experimental design}

The study was conducted on a clay loam soil near Toulouse (south-west of France). A sward of cocksfoot (Dactylis glomerata L., $c v$ Lude) was sown in the autumn of 1994 . There were three cutting treatments in 1997. Two were designed to simulate the pattern of grass growth with rotational grazing following a lenient (L: initial cut followed by 6 weeks of regrowth) or a severe ( $\mathrm{S}$ : initial cut and a further cut following 3 weeks of regrowth management) defoliation. A $6.5 \mathrm{~cm}$ stubble height was used for these treatments (Table 1). The third treatment, which simulated continuous (C) grazing, was cut every two weeks to a $7.5 \mathrm{~cm}$ stubble height to reduce possible tiller mortality following repeated cuts (Table 1). The three treatments were arranged in a randomized block design with four replications and plot size was $4 \mathrm{~m} \times 5 \mathrm{~m}$. Nitrogen supply was higher on the $\mathrm{C}$ treatment to offset the higher removal of $\mathrm{N}$ from repeated defoliation. The supplement of $\mathrm{N}$ supplied was chosen empirically, but we used a procedure based on plant analysis to control its effect a posteriori and more precisely to compare the three cutting treatments. Plots were irrigated if necessary to prevent any water stress.

\section{Measurements}

At the whole canopy level, the biomass of aerial parts was measured from samples cut at $1 \mathrm{~cm}$ above ground level once a week ( $\mathrm{S}$ and $\mathrm{L}$ treatments) or two weeks (C treatment) from day 156. There were three common sampling dates for the three defoliation regimes: day 168 (June 17), day 182 (July 1), day 196 (July 15). At each date, subplots of $0.25 \mathrm{~m}^{2}$ were randomly chosen. Tiller density was estimated 4 to 5 times during the experimental period by weighing 50 tillers from each subplot. From a subsample (of about $500 \mathrm{~cm}^{2}$ ), the areas of the laminae were measured with an area meter (LI-COR LI 3000) to calculate leaf area index (LAI) and specific leaf weight (slw). Green laminae and a subsample of whole herbage were dried at $80^{\circ} \mathrm{C}$ for $48 \mathrm{~h}$, then milled through a $0 \cdot 8 \mathrm{~mm}$ screen. Total $\mathrm{N}$ concentration was measured at each date for each plot and for the whole sample by a Kjeldahl procedure. Whole green lamina digestibility was assessed using an enzymatic method (Aufrère 1982).

One hundred to 300 tillers per plot (in order to get enough material for plant analysis) were selected at random, and the youngest mature laminae was cut. This was done on days $168,182,196$. The subsamples were subsequently weighed and measured for area. Digestibility was measured using the same procedure as for the whole green laminae. Acid-detergent fibre (ADF) and neutral-detergent fibre (NDF) were predicting using a near infrared reflectance spectroscopy NIRS procedure (NIRSystem 4500.TM, Lial laboratory, Aurillac, France). Calibration and validation of equations were performed using a Partial Least Square method (Marten \& Jensen 1982) on the first derivative of the absorption spectra (reflection mode) between 1300 and $2400 \mathrm{~nm}$. For NDF and ADF, the statistics were for number of samples (428, $313), \mathrm{R}^{2}$ calibration $(0 \cdot 95,0 \cdot 96)$, cross-validation $(0.93$, $0.94)$, means ( 49.5 and $28.2 \mathrm{~g} / 100 \mathrm{~g}$ ), minimum and maximum values $(32-70,19-43)$, standard error of calibration $(1.52,1.04)$, standard error of validation $(1 \cdot 65,1 \cdot 13)$.

Another group of subsamples were taken for the $\mathrm{L}$ and $\mathrm{S}$ treatments: lamina were separated into segments of $15 \mathrm{~cm}$ length from the tip of the lamina, or less for the later samples. In order to know the length of the base segment, the length of 40 laminae was measured and averaged. Pairs of replicates were pooled to obtain enough material for analyses.

Twenty individual marked tillers per plot ( 80 per treatment) were further identified with a plastic ring in the sward of each plot. Sheath length from the soil surface up to the ligule of the youngest mature leaf, dates of appearance for the visible leaf tip, beginning of senescence (decrease of green length) and death of 
each successive leaf were recorded either once a week for $\mathrm{S}$ and $\mathrm{L}$ treatments or every two weeks for the $\mathrm{C}$ treatment.

Global radiation and air temperature were measured daily. The average daily values over the studied period were respectively $17 \cdot 7 \mathrm{MJ} / \mathrm{m}^{2}$ and $18.8^{\circ} \mathrm{C}$.

\section{Data analysis}

The herbage nitrogen status was assessed to compare accurately the three cutting regimes, because they could have influenced the time course of nitrogen availability. Thus, the same $\mathrm{N}$ application could lead to a different amount of $\mathrm{N}$ uptake. In order to do this, we could not simply use the herbage nitrogen concentration as it decreases as the plants grow. Lemaire and Salette (1984) showed that for grasses growing with non-limiting $\mathrm{N}$ supply, the optimum $\mathrm{N}$ concentration of a sward $(\mathrm{N})$ can be related to the above-ground dry matter herbage yield (W): $\mathrm{N}=4 \cdot 8$ $(\mathrm{W})^{-0.32}$; $\mathrm{W}$ and $\mathrm{N}$ being the above-ground biomass $(\mathrm{t} / \mathrm{ha})$ and the nitrogen concentration in the herbage (\% dry matter) respectively. We used the parameters of this control curve, which is not species, management, or $\mathrm{N}$ supply dependent (Lemaire \& Gastal 1997), to calculate an index of sward nitrogen status (Ni), taken as the ratio of the measured $\mathrm{N}$ concentration $(\mathrm{N})$ of the above-ground dry matter $(\mathrm{W})$ to the optimum $\mathrm{N}$ concentration (Lemaire \& Gastal 1997). These indices are useful in interpreting agronomic data and in detecting situations where $\mathrm{N}$ nutrition is directly or indirectly involved in reducing crop yields below their potential (Lemaire \& Meynard 1997).

The effect of defoliation treatment on herbage characteristics (lamina weight, area and digestibility, tiller characteristics), was determined using analysis of variance. The relationship between lamina length (or area) of the youngest mature leaf and the sheath length was examined at the moment the leaf appeared, thereby assuming that there was only one growing leaf outside the sheath. Thus, when a leaf at insertion level (i) was observed as mature at a given sampling date, linear interpolation was used to calculate the date at which the leaf of insertion level $(i-1)$ appeared.
RESULTS

Sward characteristics at the canopy level

The average herbage nitrogen status was not very different among the three treatments, but it was highest for the $\mathrm{L}$ treatment (Table 2). It decreased throughout growth, particularly for the $\mathrm{L}$ treatment. Nitrogen uptake for the $\mathrm{C}$ treatment was balanced by the higher $\mathrm{N}$ supply. Tiller density was not different between treatments, but there was a trend $(P<0.05)$ for a decrease over time (Table 2).

\section{Standing green lamina mass, specific mass and digestibility}

Standing green lamina mass was different between the $\mathrm{L}$ and $\mathrm{S}$ treatments from the first date of measurement $(P<0 \cdot 001)$. Mass for the $\mathrm{C}$ treatment was at first intermediate between $\mathrm{L}$ and $\mathrm{S}$, in agreement with the cutting height (Table 1); then it stayed rather constant when compared to the $\mathrm{S}$ and $\mathrm{L}$ treatments just before each of the three cuts (Fig. 1a). The specific leaf mass of the whole green lamina was not different $(P>0.05)$ between the three treatments (Table 2), so treatment effects should be the same for LAI as for lamina mass.

The numbers of completely or at least partially green laminae were on average 2.5 and 4.2 per tiller (Table 2). They increased significantly during the growth period. The number of laminae at least partially green was lower for the $\mathrm{C}$ treatment, which coincided with the frequency of defoliation. The effect of time resulted from an increase in the number of laminae per tiller following defoliation. At the end of the experiment, the $\mathrm{L}$ treatment differed from the others in having a lower number of completely green laminae, and the number of at least partially green lamina was lower for the $\mathrm{C}$ treatment. These results indicate differences in tiller structure between the defoliation treatments when expressed as the number of laminae per tiller.

Digestibility of the green lamina was lower $(P<0.001)$ for the $\mathrm{L}$ treatment in comparison to $\mathrm{S}$, from the first date of measurement. Thereafter it changed at the same rate on both treatments (Fig. $1 b$ ). The average difference in lamina digestibility between these two treatments was $3 \cdot 2$ percentage

Table 1. Definition of treatments

\begin{tabular}{llcl}
\hline \hline $\begin{array}{l}\text { Defoliation } \\
\text { treatment }\end{array}$ & Cutting schedule & $\begin{array}{c}\text { Cut height } \\
\text { (cm) }\end{array}$ & Total N supply (kg/ha); (date of N supply) \\
\hline L (lenient) & 15 May & $6 \cdot 5$ & 50 (15 May) + 150 (02 June) \\
S (severe) & 15 May; 02 June & $6 \cdot 5$ & 50 (15 May) + 150 (02 June) \\
C (continuous) & 15 May; 02 June; 17 June; 30 June & $7 \cdot 5$ & 50 (15 May) + 150 (02 June) +60 (30 June) \\
\hline \hline
\end{tabular}


Table 2. Effects of treatments on sward, tiller or lamina characteristics

\begin{tabular}{|c|c|c|c|c|c|c|c|}
\hline \multirow[b]{2}{*}{ Herbage characteristics } & \multirow[b]{2}{*}{ Scale and units } & \multicolumn{3}{|c|}{ Treatments } & \multicolumn{3}{|c|}{ Significance of effects } \\
\hline & & $\mathrm{L}$ & $\mathrm{S}$ & $\mathrm{C}$ & Treatment & Time & Interaction \\
\hline Herbage nitrogen index $(\mathrm{Ni})$ & Canopy $\dagger$ & 94 & 85 & 86 & $* * *$ & NS & ** \\
\hline Tiller density $\left(/ \mathrm{m}^{2}\right)$ & Canopy & 1651 & 1744 & 1550 & NS & $* * *$ & NS \\
\hline Specific leaf mass $\left(\mathrm{g} / \mathrm{m}^{2}\right)$ & $\begin{array}{l}\text { Canopy } \dagger \\
\text { Youngest mature } \\
\text { Lamina }\end{array}$ & $\begin{array}{l}37 \cdot 2 \\
38 \cdot 0\end{array}$ & $\begin{array}{l}34 \cdot 2 \\
38 \cdot 6\end{array}$ & $\begin{array}{l}35 \cdot 0 \\
36 \cdot 5\end{array}$ & $\begin{array}{l}\text { NS } \\
\text { NS }\end{array}$ & * & $\begin{array}{l}\text { NS } \\
\text { NS }\end{array}$ \\
\hline $\begin{array}{l}\text { Number of completely green } \\
\text { laminae per tiller }\end{array}$ & Tiller & $2 \cdot 3$ & $2 \cdot 6$ & $2 \cdot 8$ & NS & $* * *$ & $* *$ \\
\hline $\begin{array}{l}\text { Number of completely or } \\
\text { partially green laminae per tiller }\end{array}$ & Tiller & $4 \cdot 5$ & $4 \cdot 3$ & $4 \cdot 0$ & $* * *$ & $* * *$ & $*$ \\
\hline $\begin{array}{l}\text { Difference in leaf insertion level } \\
\text { between two samplings }\end{array}$ & Tiller $*$ & $1 \cdot 0$ & $1 \cdot 2$ & 1.9 & $* * *$ & $* * *$ & $* * *$ \\
\hline $\begin{array}{l}\text { Difference in lamina digestibility } \\
\text { between leaf insertion } \\
\text { level }+(\mathrm{g} / \mathrm{kg})\end{array}$ & Tiller & 66 & 71 & 17 & $* * *$ & $* *$ & NS \\
\hline \multirow{2}{*}{$\begin{array}{l}\text { Difference in lamina digestibility } \\
(\mathrm{g} / \mathrm{kg}) \text { between the youngest } \\
\text { mature leaf and the previous } \\
\text { lamina }\end{array}$} & Sampling date 2 & -2 & -3 & & $* * *$ & & \\
\hline & Sampling date 3 & -33 & -33 & & $* * *$ & & \\
\hline
\end{tabular}

$*, * *, * *$ Significant at $0 \cdot 05,0 \cdot 01,0 \cdot 001$ probability levels respectively.

$\dagger$ For the weeks 2,4 and 6 .

\$ From day 168 to 182 and day 182 to 196.

+ For one leaf insertion level.
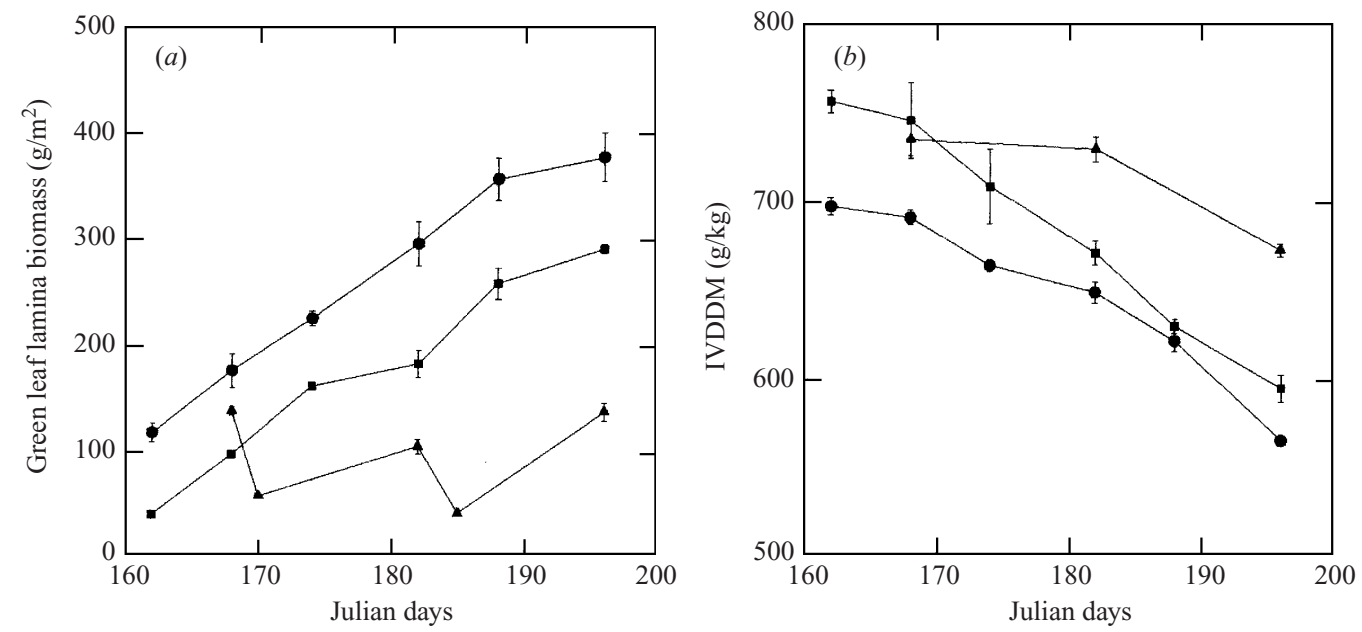

Fig. 1. Green lamina mass $(1 a)$ and digestibility $(1 b)$ for $\mathrm{L}(\mathbf{O}), \mathrm{C}(\mathbf{\Delta})$ and $\mathrm{S}(\boldsymbol{\square})$ treatments over time; vertical bars give S.E.

units. The lamina digestibility for the $\mathrm{C}$ treatment was at first lower than the $\mathrm{L}$ treatment, after which it decreased slowly, so that the lamina digestibility was significantly higher for the two last dates of measurement in the $\mathrm{C}$ treatment.
Insertion level, area and digestibility of the youngest mature lamina

The number of visible leaves per tiller differed between the treatments according to the cutting date and 

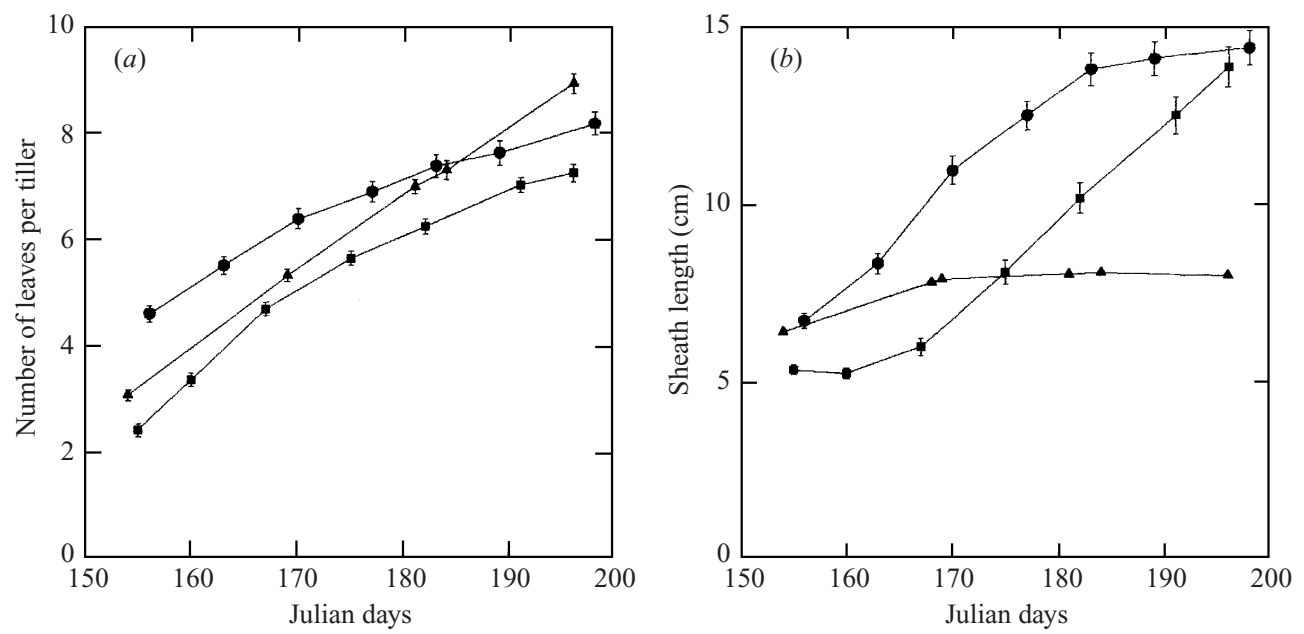

Fig. 2. Cumulated number of leaves that appeared over time per tiller $(2 a)$ and sheath length $(2 b)$ on $\mathrm{L}(\mathbf{O}), \mathrm{C}(\mathbf{A})$ and $\mathrm{S}(\boldsymbol{\square})$ treatments; vertical bars give S.E.
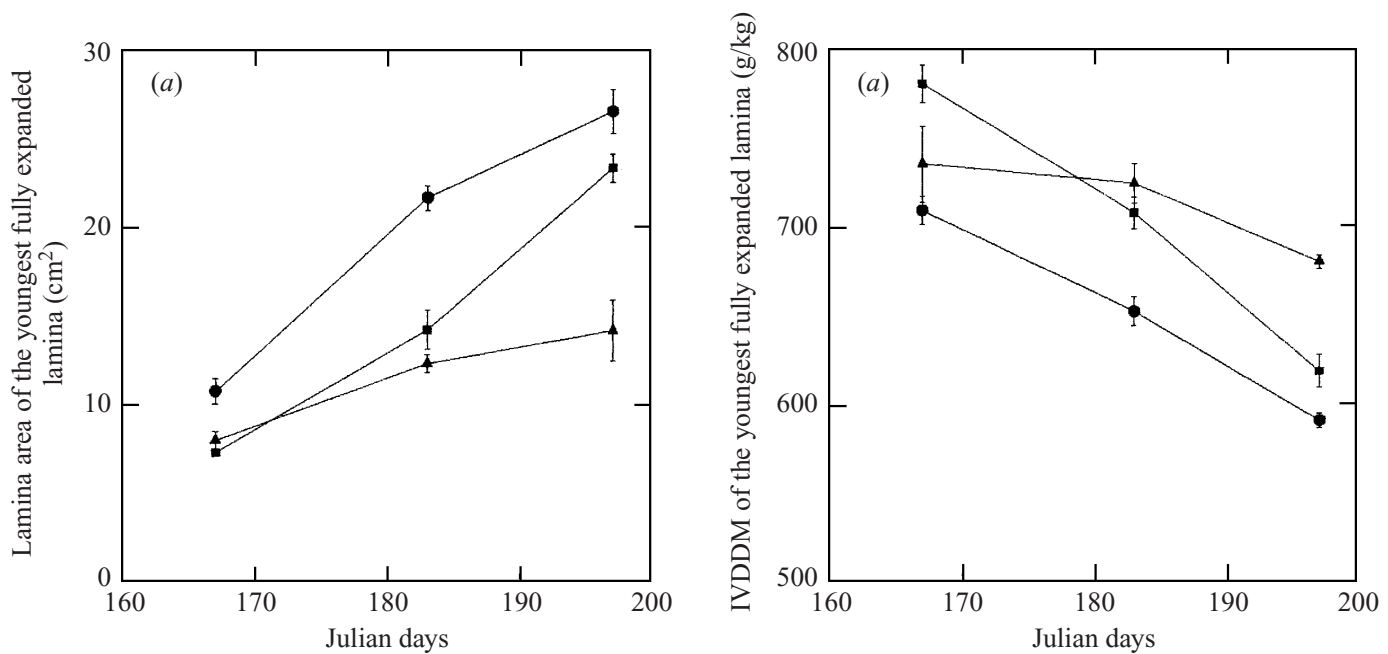

Fig. 3. Lamina area (3a) and digestibility (3b) over time of the youngest fully expanded lamina for L (O), C ( $\mathbf{\Delta})$ and $\mathrm{S}(\boldsymbol{\square})$ treatments; vertical bars give S.E.

height. Prior to day (D) 160, treatments were ranked consistently according to date and height of cut. After that, the leaf appearance rate was rather constant for the $\mathrm{C}$ treatment, while it decreased for $\mathrm{S}$ and particularly for L (Fig. 2a). As a result, the difference of leaf insertion level between D168 and D182, and between D182 and D196, was significantly different between treatments (Table 2), with it being highest for the $\mathrm{C}$ treatment.

The sheath length was highest in the L treatment. It increased at the same rate up to D180 for the S and L treatments. For C, it was stable from D165 (Fig. 2b). The average area of the youngest mature laminae increased through the study period, but the rate was lower in the $\mathrm{C}$ treatment, so that the area was significantly lower in the $\mathrm{C}$ treatment at the third sampling date (Fig. $3 a$ ). The specific lamina weight was not significantly different between treatments (Table 2), so treatment effects should be the same whether we consider weight or area.

The average area of the youngest mature lamina (AYLa) was positively correlated $(P<0.001)$ with the sheath length (ShL) at the moment when the leaf appeared (data not shown).

$$
\text { AYLa }=-12 \cdot 5+3 \cdot 2 \mathrm{ShL} ; r^{2}=0 \cdot 91 \text {, S.E. }=2 \cdot 1 \text { (1) }
$$

In other words, the treatment in which the increase in sheath length was the lowest also had the least 

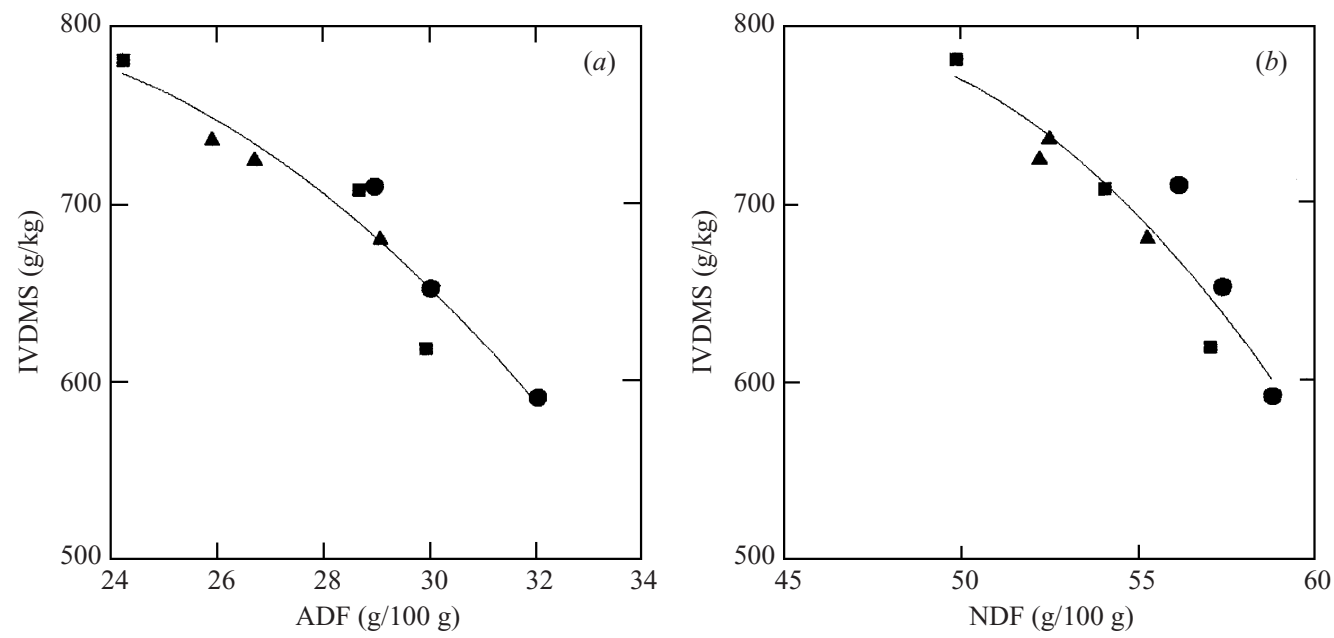

Fig. 4. Regression between digestibility of the youngest fully expanded lamina and its $\operatorname{ADF}(a)$ and NDF $(b)$ concentrations for $\mathrm{L}(\boldsymbol{\bullet}), \mathrm{C}(\boldsymbol{\Delta})$ and $\mathrm{S}(\boldsymbol{\square})$ treatments.

Table 3. Digestibility of lamina segments and average length (cm, given in brackets) of these segments

\begin{tabular}{|c|c|c|c|c|}
\hline \multirow[b]{2}{*}{ Sampling date } & \multirow{2}{*}{$\begin{array}{l}\text { Lamina } \\
\text { segments }\end{array}$} & \multicolumn{2}{|c|}{ Lamina digestibility $(\mathrm{g} / \mathrm{kg})$} & \\
\hline & & $\mathrm{S}$ & $\mathrm{L}$ & \\
\hline \multirow[t]{2}{*}{1} & 1 & $817(15)$ & $770(15)$ & \\
\hline & 2 & $714(3)$ & $636(9)$ & \\
\hline \multirow[t]{3}{*}{2} & 1 & $817(15)$ & $787(15)$ & \\
\hline & 2 & $681(13)$ & $645(12)$ & \\
\hline & 3 & & $576(5)$ & \\
\hline \multirow[t]{4}{*}{3} & 1 & $785(15)$ & $769(15)$ & \\
\hline & 2 & $675(15)$ & $672(15)$ & \\
\hline & 3 & $534(12)$ & $562(12)$ & \\
\hline & 4 & & $476(8)$ & \\
\hline \multicolumn{2}{|l|}{ S.E. (D.F.) } & $4 \cdot 4(13)$ & $3 \cdot 0(17)$ & \\
\hline \multirow{2}{*}{$\begin{array}{l}\text { Selection of } \\
\text { segments } \dagger \text { and dates }\end{array}$} & \multicolumn{4}{|c|}{ Significance of the effects } \\
\hline & Segments & Cutting regime & Sampling date & Date* segments \\
\hline Segments $<2$ & - & NS & * & - \\
\hline Segments $<3$, date $>1$ & $* * *$ & $*$ & NS & * \\
\hline Segments $<4$, date $>2$ & $* * *$ & NS & NS & NS \\
\hline
\end{tabular}

$\dagger$ From segments 1 for the top; lamina segments were equal or less than $15 \mathrm{~cm}$; significance of the effects for different sets of variables: $* * * *$ significant at $0 \cdot 05,0 \cdot 001$ probability levels respectively.

lamina area increase (treatment C). Furthermore, at a given date, the shorter the sheath length when the lamina emerged, the lower its area at maturity.

The digestibility of the youngest mature lamina was lowest for the $\mathrm{L}$ treatment at the three dates of measurement (Fig. 3b). Digestibility for $\mathrm{S}$ was consistently higher than for L. The digestibility of the youngest mature lamina on the $\mathrm{C}$ treatment was initially intermediate between those of $\mathrm{L}$ and $\mathrm{S}$; but decreased more slowly through the experiment period and was at least 8 percentage units higher at the end than the other two treatments. The decrease in lamina digestibility between the leaf insertion levels, translated into a difference in lamina digestibility between successive leaves, and was at least three times lower for the $\mathrm{C}$ treatment compared with the two other 
Table 4. Regressions and correlations between sward characteristics

\begin{tabular}{|c|c|c|c|c|c|}
\hline Dependent variable & Independent variables & D.F. & S.E. & $P$ & $R^{2}$ \\
\hline Digestibility of the green lamina & $\begin{array}{l}\text { Digestibility of the youngest mature } \\
\text { lamina }\end{array}$ & 8 & $1 \cdot 6$ & $0 \cdot 0001$ & 0.93 \\
\hline \multirow{2}{*}{ Digestibility of the green lamina } & Green lamina mass & 8 & $2 \cdot 3$ & $0 \cdot 01$ & $0 \cdot 86$ \\
\hline & Leaf area index & 8 & $2 \cdot 2$ & $0 \cdot 0001$ & $0 \cdot 87$ \\
\hline $\begin{array}{l}\text { Digestibility of the youngest mature } \\
\text { lamina }\end{array}$ & Sheath length & 8 & $1 \cdot 5$ & $0 \cdot 0001$ & $0 \cdot 94$ \\
\hline
\end{tabular}
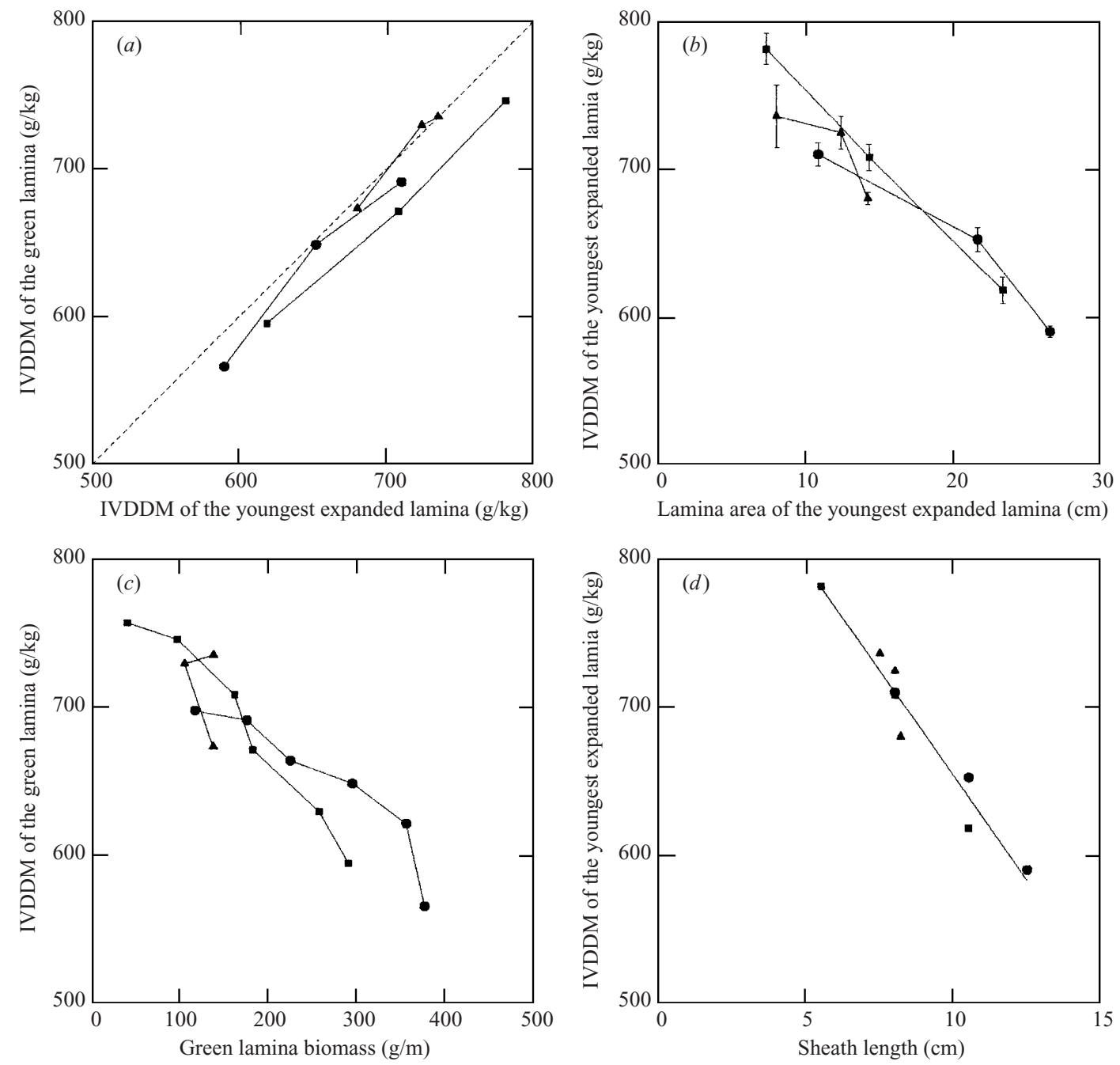

Fig. 5. Digestibility of the whole green lamina versus those of the youngest fully expanded lamina ( $5 a$ ) or green lamina biomass $(5 c)$; digestibility of the youngest fully expanded lamina versus its area $(5 b)$ or the sheath length when it emerged $(5 d)$ for $\mathrm{L}(\boldsymbol{\bullet}), \mathrm{C}(\boldsymbol{\Delta})$ and $\mathrm{S}(\boldsymbol{\square})$ treatments; vertical bars give S.E.

treatments (Table 2). ADF and NDF concentrations in the youngest mature lamina gave a good fit for digestibility using a quadratic function, for all treatments and sampling dates $(P<0 \cdot 001$, Fig. 4$)$.
At a given date, the digestibility of the youngest mature lamina (insertion level $\mathrm{n}$ ) was lower than the previous older, one, (insertion level $\mathrm{n}-1$ ) (Table 2). The youngest mature lamina was less digestible, both 
for the $\mathrm{L}$ and $\mathrm{S}$ treatment, at the second and particularly the third sampling dates, if a comparison could be made.

\section{Digestibility of lamina segments}

The digestibility of the different lamina segments always decreased $(P<0.001)$ from the tip to the base of the lamina (Table 3). In order to have samples where the number and the length of the segments were similar, we selected appropriate data. The digestibility of the tip of the lamina tended to be greater for the $\mathrm{S}$ treatment, but not significantly so (Table 3 ). For the tip segments and the adjacent ones (two last sampling dates), there was a significant effect of cutting regime. For leaf tip and adjacent segment (last sampling date), there was a difference only between segments.

\section{Lamina digestibility according to leaf and tiller characteristics}

Digestibility of the youngest mature lamina (DYLa) was correlated $(P<0 \cdot 001)$ to that of the whole green lamina, for both treatment and sampling date (Table 4). Digestibility of the youngest mature leaf was on average slightly higher (Fig. $5 a$ ).

Digestibility of the youngest mature lamina was closely correlated $(P<0.001)$ with area for all treatments and sampling dates (Table 4, Fig. 5c):

$$
\text { DYLa }=81.8-0.84 \text { AYLa } ; r^{2}=0 \cdot 92, \text { s.E. }=1.69
$$

Digestibility of the whole green laminae was also correlated $(P<0 \cdot 001)$ with biomass (Fig. 5c, Table 4).

By combining equations (1) and (2) it was possible to express the digestibility of the youngest mature lamina at insertion level (i) as a function of the sheath length at insertion level ( $i-1)$, (Fig. $5 d$, Table 4). Thus the model can determine differences in digestibility resulting both from normal ontogenic drift (successive leaf insertion levels during growth) and from defoliation regimes. The sheath length at the moment the lamina tip emerges outside the sheath appears to be a satisfactory indicator of digestibility at maturity.

\section{DISCUSSION}

Greater $\mathrm{N}$ supply on the $\mathrm{C}$ treatment maintained the herbage nitrogen status at a similar level to the others although there was potentially more $\mathrm{N}$ uptake in relation to the defoliation frequency. In our experiment, the differences in herbage nitrogen status between treatments were small. The index of sward nitrogen status (Ni) reflects the actual herbage production in relation to the potential one. It indicates that herbage production varied from 85 to $94 \%$ of the potential growth (Table 2). These values are higher than those usually observed without $\mathrm{N}$ supply (Ni about 50) in the same soil (Duru et al. 1995). As $\mathrm{N}$ application on swards usually has little effect on herbage digestibility (Hacker \& Minson 1981; Demarquilly 1989), we conclude that differences observed in $\mathrm{N}$ herbage status between treatments in our experiment did not induce differences in digestibility.

The range of variation of sheath length (from 5 to $15 \mathrm{~cm}$ ) obtained during the investigation in response to different cutting treatments reflects those observed in pastures dominated by cocksfoot and grazed by cows on dairy farms in the south-west of France: length minimum $=3 \cdot 7$, maximum $=23 \cdot 7$, mean $=$ 9.8, S.D. $=3.7 \mathrm{~cm}, n=90$ (after Ducrocq \& Duru 1995). This suggests that mechanical defoliation can mimic grazing for this sward characteristic.

The digestibility of the youngest mature lamina was highly correlated with the digestibility of pooled green laminae. Because there were only four green leaves, the higher digestibility of the youngest offset the lower digestibility of the two oldest leaves. So the plant characteristics used to assess digestibility or its variation throughout growth or with different defoliation regimes can be used both at the lamina and the tiller levels.

\section{Sheath length could explain the digestibility pattern throughout growth at lamina and tiller levels}

To analyse the effect of treatment on lamina digestibility, we must first explain the change in the digestibility of laminae during growth. As Wilson (1976a) also showed, we observed differences in digestibility with leaf insertion, and the digestibility of the youngest mature lamina was lower than that of the oldest one. Wilson (1976b) showed that it was a result of anatomical and chemical differences (greater proportions of sclerenchyma and lignin). However, we found that the rate of decrease between two leaf insertion levels was very variable according to cutting treatment, and was three times lower for C. This is why the leaf insertion level, considered alone, is not sufficient to make a model of leaf digestibility as suggested previously (Wilson 1976a).

The lamina can be regarded as an assemblage of two main components, one metabolic, the other structural (Caloin \& Yu 1984). The proportion of the structural component increases with leaf length. For example, it was shown that for sweet sorghum leaves, the mass of the midrib increases proportionately more than the total lamina mass (Lemaire \& Gastal 1997). Hence as individual plants accumulate successive leaves of increasing size, the accumulation of structural components of plant biomass is more rapid than the accumulation of the metabolic component associated with leaf area. The digestibility of lamina segments suggests an increase in structural components from the tip to the base, as Maurice et al. (1997) 
observed. Moreover, we can mainly interpret the difference in digestibility of the whole youngest mature lamina from one insertion level to the next as the addition of a less digestible segment. These differences can be regarded as a decrease in the proportion of the metabolic component, because lamina digestibility was well correlated with ADF and NDF concentrations (Fig. 4). The decrease in digestibility of the whole green lamina during tiller development did not simply result from leaf ageing, because the number of leaves, after a short increase, remained the same during the regrowth period. This trend results mainly from the appearance of new leaves which are longer in relation to the sheath length, but less digestible. So, we believe that grazing management, which could affect the sheath length and consequently the lamina characteristics, could have an effect on digestibility. This hypothesis was used to analyse the effect of defoliation.

\section{Defoliation regimes could govern lamina digestibility through sheath length}

We observed a significant effect of cutting treatments on lamina digestibility, for both the youngest mature laminae and the whole green laminae. These results are in agreement with those observed under grazing conditions. In numerous studies, it has been observed that herbage quality increases as grazing severity increases in a rotational (Kristensen 1988) or a continuous (Binnie \& Chestnutt 1994) grazing system. This trend was interpreted as a result of a lower proportion of stem and less mature leaf material. Our results suggest that these differences could also have resulted from differences in the digestibility of the green lamina. Moreover, Hoogendoorn et al. (1992) also observed a significantly greater herbage digestibility for treatments where there was a lower residual herbage mass. The difference in digestibility was observed not only for total herbage but also for grass leaf for two of their three experiments.

In the absence of repeated defoliation (treatments $\mathrm{L}$ and $\mathrm{S}$ ), the sheath length depends on its initial length, and also on its increase from one leaf insertion level to the next. This increase, which depends on nitrogen availability and temperature, was quite similar for $\mathrm{L}$ and $\mathrm{S}$ treatments $(2$ and $2.4 \mathrm{~cm}$ respectively). The difference in sheath length from the first sampling date and its subsequent time course could explain both differences in digestibility at a given date and its dynamics, which were rather similar for the two treatments. In contrast, for the $\mathrm{C}$ treatment, which involved cutting every two weeks, the increase in sheath length from one leaf insertion level to the next was smaller. We think that the small differences in lamina digestibility accord with the appearance of leaf with similar characteristics, in keeping with a constant sheath length.

To model lamina digestibility, the proposed hypothesis eliminates the need for knowledge of the sward state at the time of defoliation or the time elapsed since this defoliation. Knowing the sheath length appears to be sufficient to assess lamina digestibility. This result indicates that it will be possible to manipulate the sward through defoliation intensity and frequency in order to achieve a given herbage digestibility. However, it is necessary to find a biological basis for this phenomenon. Three facts could provide an explanation: (i) leaf tip emergence above the sheath and into the light is considered as a mechanism which could regulate cell production, stopping it (Skinner \& Nelson 1995), (ii) the period of growth of the leaf through the sheath tube increases from one leaf insertion level to the next (Groot \& Neuteboom 1997), and (iii) there is a gradient of structural tissue from the tip to the base of the lamina. So, we could hypothesize that metabolic changes are related to leaf growth duration inside the sheath. It should be verified that the first cells produced in a leaf are the most digestible, and that the digestibility of subsequent cells declines the later they are produced. Thus the duration of growth of a leaf inside the sheath could determine its digestibility when mature.

\section{CONCLUSION}

Contrasting defoliation regimes applied to a vegetative sward of cocksfoot resulted in differences in lamina digestibility of up to 100 within a range from 600 to $800 \mathrm{~g} / \mathrm{kg}$. The same model based on the sheath length allows us to interpret both the time course of the digestibility decrease and the effect of defoliation regime. The differences were associated with similar differences in lamina weight and area, which were linked to sheath length. Sheath length is a simple criterion that has potential for manipulating the sward to achieve a target herbage digestibility.

\section{REFERENCES}

Aufrère, J. (1982). Etude de la prévision de la digestibilité des fourrages par une méthode enzymatique. Annales Zootechniques 31, 11-130.

Binnie, R. C. \& Chestnutt, D. M. B. (1994). Effect of stocking by sheep at four sward heights on herbage mass, herbage quality and tissue turnover on grass/clover and nitrogen-fertilized grass swards. Grass and Forage Science 49, 192-202.

Caloin, M. \& Yu, O. (1984). Analysis of the time course change in nitrogen content of Dactylis glomerata L. using a model of plant growth. Annals of Botany 54, 69-76.

Davies, A. (1988). The regrowth of grass swards. In The 
Grass Crop (Eds M. B. Jones \& A. Lazenby), pp. 85-117. New York: Chapman and Hall Ltd.

Demarquilly, C. (1989). The feeding value of forages. In Proceedings of the XVI International Grassland Congress (Ed. R. Desroches), pp. 1817-1823. Nice, France.

DucrocQ, H. \& Duru, M. (1995). Croissance brute et pertes par litière de feuilles de Dactylis glomerata (L.). Evaluation de conduites de pâturage tournant dans des èlevages laitiers du Sud-Ouest de la France. IV Symposium International sur la nutrition des Herbivores. Clermont Ferrand. Annales de Zootechnie 44 Suppl., 337.

Ducroce, H. \& Duru, M. (1996). Effet de la conduite d'un pâturage tournant sur la digestibilité de l'herbe offerte. Fourrages 145, 91-104.

Duru, M., Ducroce, H. \& Tirilly, V. (1995). Modeling growth of cocksfoot (Dactylis glomerata L.) and tall fescue (Festuca arundinacea Shreb.) at the end of spring in relation to herbage nitrogen status. Journal of Plant Nutrition 18, 2033-2047.

Fick, G. W., Wilkens, P. W. \& Cherney, J. H. (1994). Modeling forage quality changes in the growing crop. In Forage Quality, Evaluation and Utilization (Eds G. C. Fahey et al.), pp. 757-795. Madison, WI: American Society of Agronomy, Inc.

Grant, S. A., Barthram, G. T. \& Torvel, L. (1981). Components of regrowth in grazed and cut Lolium perenne swards. Grass and Forage Science 36, 155-168.

Groot, C. J. J. \& Neuteboom, J. H. (1997). Composition and digestibility during ageing of Italian ryegrass leaves of consecutive insertion levels. Journal of the Science of Food and Agriculture 75, 227-236.

HaCker, J. B. \& Minson, D. J. (1981). The digestibility of plant parts. Herbage Abstracts 51, 459-482.

Hoogendoorn, C. J., Holmes, C. W. \& Chu, A. C. P. (1992). Some effects of herbage composition, as influenced by previous grazing management on milk production by cows grazing on ryegrass/white clover pasture. 2-Milk production in late spring/summer effects of grazing intensity during the preceeding spring period. Grass and Forage Science 47, 316-325.

KRISTENSEN, E. S. (1988). Influence of defoliation regime on herbage production and characteristics of intake by dairy cows as affected by grazing intensity. Grass and Forage Science 43, 239-251.

Lemaire, G. \& Gastal, F. (1997). N uptake and distribution in plant canopies. In Diagnosis of the N Nutrition Status in Crops (Ed. G. Lemaire), pp. 3-44. Berlin: Springer Verlag.
Lemaire, G. \& Meynard, J. M. (1997). Use of the nitrogen nutrition index for the analysis of agronomical data. In Diagnosis of the $N$ Nutrition Status in Crops (Ed. G. Lemaire), pp. 45-55. Berlin: Springer Verlag.

Lemaire, G. \& Salette, J. (1984). Relation entre dynamique de croissance et dynamique de prélèvement d'azote pour un peuplement de graminées fourragères. I. Etude de l'effet du milieu. Agronomie 4, 423-430.

Marten, H. \& Jensen, S. A. (1982). Partial least squares regression: a new two stages NIR calibration method. In Proceedings of 7th World Cereal Bread Congress (Eds C. Holas \& Y. Katchovil), pp. 607-647. Amsterdam: Elsevier.

Maurice, I., Gastal, F. \& Durand, J. L. (1997). Generation of form and associated mass deposition during leaf development in grasses: a kinetic approach for non steady growth. Annals of Botany 80, 673-683.

Penning, P. D., Parsons, A. J., Orr, R. J. \& Hooper, G. E. (1996). Intake and behaviour responses by sheep to changes in sward characteristics under rational grazing. Grass and Forage Science 49, 476-486.

Silsbury, J. H. (1970). Leaf growth in pastures. Tropical Grasslands 4, 17-36.

SkinNer, R. H. \& Nelson, C. J. (1995). Elongation of the grass leaf and its relationship to the phyllochron. Crop Science 35, 4-10.

Van Loo, E. N. (1993). On the relation between tillering, leaf area dynamics and growth of perennial rye grass. $\mathrm{PhD}$ thesis, Agricultural University, Wageningen, The Netherlands.

WILKINS, R. J. (1995). Optimisation of grass utilisation in high rainfall temperate conditions. In Recent developments in the nutrition of herbivores. Proceedings of the IVth Internationl Symposium on the nutrition of herbivores (Eds M. Journet, E. Grenet, M. H. Farce, M. Thériez \& C. Demarquilly), pp. 363-380. Versailles, France: INRA Editions.

WILSON, J. R. (1976a). Variation of leaf characteristics with level of insertion on a grass tiller. I. Development rate, chemical composition and dry matter digestibility. Australian Journal of Agricultural Research 27, 343-354.

WILSON, J. R. (1976b). Variation of leaf characteristics with level of insertion on a grass tiller. II. Anatomy. Australian Journal of Agricultural Research 27, 355-364.

Wilson, R. E. \& Laidlaw, A. S. (1985). The role of the sheath tube in the development of expanding leaves in perennial ryegrass. Annals of Applied Biology 106, 385-391. 